DOI 10.37882/2500-3682.2020.06.12

\title{
МЕЖЭТНИЧЕСКОЕ ВЗАИМОДЕЙСТВИЕ И ФОРМИРОВАНИЕ РУССКОГО НАСЕЛЕНИЯ В ТУВЕ
}

\section{INTERETHNIC INTERACTION AND FORMATION OF THE RUSSIAN POPULATION IN TUVA}

\section{S. Mongush}

Summary: The aim of the study is to reveal the essence and specificity of interethnic interaction of Russian and the Tuvan population and adaptation of Russian settlers in Tuva and the formation of the Russian population. Scientific novelty-the study provides a socio-philosophical analysis of the problems of interethnic interaction between the Russian and Tuvan populations in the context of several centuries. As a result, the author's conclusions provide a wide panorama and new information about the history, culture, and life of Russians in Tuva.

Keywords: Russian Russians, Tuvans, Russian-Tuvans, old believers, Uriankhai region, Tuva people's Republic, Republic of Tuva, interethnic interaction, interethnic relations, migration, adaptation, assimilation.

\author{
Монгуш Салбак Онер-ооловна \\ К.ф.н., дочент, ФГБОУ ВО «Тувинский государственный \\ университет» \\ monghush.1975@mail.ru
}

Аннотация: Цель исследования - выявить сущность и специфику межэтнического взаимодействия русского и тувинского населения и адаптации русских поселенцев в Туве, а также формирование русского населения республики. Научная новизна - в исследовании дана социально - философский анализ проблем межэтнического взаимодействия русского и тувинского населения в разрезе нескольких столетий. В результате сделанные автором выводы дают широкую панораму и новую информацию 06 истории, культуре, всей жизнедеятельности русских в Туве.

Ключевые слова: Тува, межэтническое взаимодействие, межэтническое отношение, переселение, адаптация, ассимиляция, русские, тувинцы, русскотувинские связи, старообрядцы, Урянхайский край, Тувинская Народная Республика, Республика Тыва.
$A$ ктуальность темы: в данной статье рассматривается проблема межэтнического взаимодействия и формирования русского населения в разрезе нескольких столетий. Проанализирована история переселения в Туву русских переселенцев и их адаптационные процессы, которые проходили в разные исторические периоды в три этапа: Несмотря на наличие научных работ по истории советско-тувинских отношений, практически отсутствует комплексных исследований по межэтническим отношениям и формирования русского населения в разные периоды на территории Урянхайского края, ныне Республики Тыва. В силу того, что данный аспект мало исследован, проблема в такой постановке рассматривается впервые. И в свою очередь, автор актуализирует необходимость специального изучения проблем русского населения, включая историю его формирования, расселения, особенности социально-культурных условий жизнедеятельности, адаптации и межнационального взаимодействия. Русские переселенцы, несмотря на экономические и культурные различия, не встречали существенных преград и стеснений в своей жизни и деятельности в Урянхайском крае.

Исследование имеет междисциплинарный характер на стыке философии и этнологии. При этом основными методами, применявшимися в исследовании, были исторические и социально-философские методы. Особое место отводилось принципу историзма, системному подходу, структурному анализу, при этом использовался понятийно-категориальный аппарат этнологии.

В результате исследования автор делает вывод о том, что межэтническое взаимодействия русских с тувинцами протекало мирно и благополучно. Расселяясь на новых землях, переселенцы обретали здесь и новую родину. Живя в новых местах из поколения в поколение, русские не только приживались, но постепенно становились, по существу, коренными жителями края. При этом они, разумеется, не утратили этногенетической и культурноязыковой общности с основным ядром русского народа как этническим целым, выступая его территориальными частями, которые, естественно, в течение ряда поколений, приобретали здесь некоторые особенности образа жизни, быта, обычаев и традиций, даже менталитета.

Все известные человеческие общности живут определенными сообществами - этносами, нациями, этническими группами. Народы и нации объединены между собой разнообразными связями - историческими, языковыми, культурными, хозяйственно-экономическими, социально-политическими, и вся их целостность представляет собой систему межэтнических (национальных) отношений.

Межэтнические отношения изучаются такими науками, как социология, культурная антропология, политология, история, экономика, социальная психология, демография и др. При рассмотрении межэтнических 
отношений будем использовать принципы социальнофилософского подхода, при этом используя методологию и данные исторического исследования, вместе с тем придерживаться понятийно-категориального аппарат этнологии.

В мировой науке нет четкости в определении области межэтнических отношений. В гуманитарных науках она именуется различными понятиями как «межгрупповое поведение», «межгрупповые отношения», (в этнопсихологии); «национальные и межнациональные отношения», «национальные конфликты» (в социологии); «межэтнические и этнические отношения», «этнические процессы» (в этнологии).

В отечественной социальной философии (подобно социологии) наиболее употребительными являются понятия «национальные» и «межнациональные» отношения. В последнее время в связи с возрастанием роли и значения этнологического знания соответствующая «этническая» терминология стала широко проникать в содержание гуманитарных и социальных наук, а также социальной философии. Поэтому в последние годы довольно активно стали употребляться термины и понятия - «межэтнические отношения», «этнические отношения», хотя эти понятия еще не стали философскими.

При анализе, кроме понятия «межэтнические (межнациональные) отношения», используем термин «межэтническое взаимодействие», поскольку он включает в себя широкий спектр связей и отношений между народами (этносами), показывает как конфронтационные, так и интеграционные процессы.

В отечественной литературе этот термин и содержание понятия недостаточно разработан. Довольно содержательное обозначение этого понятия дал А.Д. Карнышев в своей работе «Межэтническое взаимодействие в Бурятии: социальная психология, история, политика». Он пишет: «Межэтническое взаимодействие - это прежде всего разнообразные контакты между этносами, ведущие к изменению индивидуальных и совокупных характеристик каждой из взаимодействующих этнических групп и их отдельных представителей, а также к интеграции их определенных качеств и свойств» [8; 53]. При анализе межэтнического взаимодействия русских с тувинцами в условиях переселения в Урянхайский край мы вернемся к термину «межэтническое взаимодействие».

В социологической литературе в межэтнических взаимодействиях специалисты выделяют несколько групп взаимозависимых факторов: исторических, политических, социальных, культурных, психологических, ситуативных $[1 ; 193]$. Рассмотрим влияние некоторых из них на область межэтнических отношений, имея в виду, что межэтническое взаимодействие само выступает факто- ром развития этнической идентичности взаимоконтактирующих народов, в данном случае русских.

Прежде чем рассмотреть, как происходило межэтническое взаимодействие между русскими и тувинцами, следует отметить, что фактически отсутствуют специальные крупные работы по данной теме как дореволюционного, советского, так и современного периодов. В историографии в настоящее время по этому вопросу имеется лишь весьма незначительное число работ, в основном это статьи.

Исследования советского и постсоветского периода русский вопрос получил освещение главным образом в исторической и этнографической литературе в трудах Л.М. Дробижевой, Н.М. Моллерова, 3.В. Анайбан, Г.Ф. Балакиной, Н.П. Москаленко.

В фундаментальном труде «История Тувы» наиболее подробно излагается проблемы истории возникновения и развития русско-тувинских связей. По современной местной литературе особый интерес представляет труды М.П. Татаринцевой и А.А. Стороженко которые исследовали о старообрядцах в XVIII - XIX веков, их последующей жизни в крае, современные особенности быта.

На рубеже XVI - XVII вв. началось взаимодействие русского и тувинского этносов. На протяжении XVII - XVIII вв. тувинские племена присягали на верность русскому царю. Русско-тувинские связи в дальнейшем стали осуществляться в виде торгового обмена, инициаторами которого были казаки-пограничники, а покупателями - тувинцы, жители Урянхайского края. В этой связи большой интерес, представляет работа А.М. Африканова, автор пишет, « что первыми, кто начал занимать торговлей в Урянхайском крае, были казаки, в обязанности которых входило наблюдение как за целостностью пограничных линий, так и за тем, чтобы соседние племена урянхов не переходили границу и не грабили у русских скот. Производя объезд, казаки занимались меной торговлей с тувинскими и монгольскими чиновниками, съезжаясь в определенные места. Казаки первоначально выменивали разные пряжи, мелкие товары, табак, а затем стали завозить мануфактурные товары. Тувинцы торговали в основном пушниной» $[2 ; 35]$. Первыми из русских в верховья Бий-Хема проникли золотоискатели и приверженцы старой веры.

В последние десятилетия XIX в. безземельные русские крестьяне стали проникать в Урянхайский край несанкционированно. Именно в те годы крестьянское переселенческое движение охватило всю Россию. В основном это были немногочисленные старообрядцы, которые искали уединения, спокойствия и земли обетованной. Русские об Урянхайском крае говорили, что «там много свободной земли, богатая зверем, птицей и 
орехом тайга, великое множество рек и озер с рыбой и т.д.». $[16 ; 17]$.

За староверами в Туву стали переселяться и сибирские купцы разного толка и предприниматели. Именно они положили начало обоснованию русского торгового капитала в Урянхайском крае. Купцы открыли целый ряд торговых факторий, привозили в край массу товаров. Сибирский историк В.И. Дулов в своей работе написал, что Тува в это время была экономически тесно связана с Россией $[5 ; 75]$.

Учитывая потребности населения и отсутствие конкуренции, русские купцы привозили в край различные товары, предметы галантереи, изделия бытового назначения, оружие, боеприпасы и др. Эти товары в основном предназначались для низших слоев тувинского общества. Как справедливо отмечал Н.Ф. Катанов, «товары русских купцов в основном покупала тувинская беднота, в то время как потребности в одежде тувинской знати (феодалов, нойонов, высших представителей духовенства) удовлетворяли китайские купцы» [6; 367].

Более богатые и предприимчивые русские купцы, подкупая тувинских чиновников, стали открывать приисковую добычу золота. Также они построили солеваренные и кожевенные заводы.

K началу XX века русские крестьяне стали проникать в Туву массово, в основном переселялись крестьяне из Минусинского уезда Енисейской губернии. Фактически это был процесс крестьянской колонизации, обусловленной Столыпинской аграрной реформой и стремлением русского государства переместить безземельных крестьян, а в Туве как раз такие земли были.

В начале XX века русское правительство создало орган Переселенческого управления для организованного переселения русских крестьян, и условия переселения русских крестьян в Туву стали более благоприятными. После установления в 1914 году протектората России над Урянхайским краем количество русских переселенцев из России в Туву увеличилось в несколько раз «численность русского населения Тувы, в те годы постоянно возрастала. Русские переселенцы сосредоточивались преимущественно в центральной (бассейн р. Хемчик) и северо-восточной (бассейн р. Каа-Хем) частях Тувы, существенно влияя на изменения этнического состава в заселяемых районах, где этнические русские начали составлять существенную часть населения» $[11 ; 43]$.

В конце 1914 г. на 50 тыс. тувинцев приходилось 5 тыс. русских переселенцев (русские составляли тогда 10\% населения) [3; 26]. По некоторым данным, в Туве в те времена было создано 256 русских поселений, в основном заимки и торговые фактории, из них 44 поселка (типа села) [4; 576]. Следует отметить, что если в 1910 г. общее количество русского населения Тувы составляло немногим более двух тысяч человек, то к концу 1919 году; оно составило 12 тыс. человек [6; 325].

Русские переселенцы осваивали широкие пространства с различными природными условиями Урянхайского края, более выносливые крестьяне заселялись в Тодже, несмотря на ее суровый климат. К 1914 г. переселенцы засеяли более двух тысяч десятин земли лесостепных территорий, они обеспечивали хлебом не только себя, но и тувинское население, которое под влиянием русских стало привыкать к хлебу.

Таким образом, для этого периода характерен более динамичный переселенческий поток, когда численность переселенцев постоянно возрастала из года в год.

Следующий этап переселения русских в Туву продолжился после образования Тувинской Народной Республики (ТНР) в 1921 г. Русское население новообразованной республики в соответствии с законодательными актами РСФСР и ТНР образовало Русскую самоуправляющую трудовую колонию (РСТК) и имело достаточную автономию, осуществляло социально-экономические и культурные связи с тувинским населением.

По некоторым данным, число русских в РСТК в 1931 году составляло около $21 \%$ всего населения ТНР (т.е. около 17 тыс. человек) [6; 242].

Молодая республика почти не имела профессиональных управленцев, технической интеллигенции, и в THP по договоренности были приглашены разные специалисты, сельскохозяйственные работники, так же направлены медико-санитарные работники для организации медицинского обслуживания населения.

Выступая в роли первых учителей и наставников, русские специалисты (многие из которых были направлены из Москвы и других регионов страны) оказывали всестороннюю помощь в подготовке национальных кадров интеллигенции не только в массовых профессиях, но и в искусстве, литературе, науке. Русская интеллигенция занимает важное место в политической жизни республики. Работали в общественных организациях, в аппарате управления органов и организаций.

Рассмотрев проблемы переселения русских в Туву, перейдем к анализу «межэтнического взаимодействия» с местным тувинским населением. Для этого вернемся к определению и понятию «межэтнического взаимодействия». Межэтнические контакты весьма разнообразны и имеют многовариантный характер, особенно на личностном уровне. В этнологической литературе принято различать несколько уровней межэтнических 
контактов - прибавление, убавление, усложнение, объединение. Межэтнические контакты могут быть неодинаковыми и по своим результатам - быть позитивными или негативными, заканчивающимися количественными изменениями и структурными превращениями. Так, по масштабам и глубине проникновения межэтнические коммуникации делятся на три основных типа - «ассимиляцию, адаптацию и интеграцию» $[15 ; 215]$.

Следует отметить то, что межэтническое взаимодействие русских переселенцев с местным населением было неодинаковым в разные исторические периоды. На первом этапе переселения - в конце XIX века - количество переселенцев было незначительным, и преимущественно это были старообрядцы, купцы и безземельные крестьяне. Межэтническое взаимодействие выражалось в виде торговых отношений.

Обживаясь на новых землях, свои поселения русские переселенцы создавали в виде таких, какие оставили в России. Всемирно известный ученый-тюрколог и исследователь Тувы Ф.Я. Кон, во время экспедиции в 1903 г. в Урянхайский край, посетивший село Туран, построенное русскими переселенцами, «отметил - что оно ничем не отличается от обычных сибирских сел» [10; 22].

Русские деревни представляли собой закрытую общину. Компактно селясь и проживая, русские старообрядцы тщательно сохраняли свои традиции и обычаи, культурные навыки. Это проявлялось в том, что любая старообрядческая семья жила в условной изоляции от тувинцев. В то же время первые переселенцы умели говорить на языке местного населения (тувинский язык). Это связано с тем, что повседневная жизнь, хозяйственные связи заставляли учить язык. Правда, особого интереса к духовной культуре тувинцев русские обычно не проявляли и в их жизнь и дела старались не вмешиваться.

Самым типичным жильем крестьян-переселенцев, в том числе и старообрядцев, была бревенчатая изба, при которой также имелись баня, амбар, сарай. Они продолжили в Урянхайском крае привычную хозяйственную деятельность - огородничество, пчеловодство, домашнее ткачество, стойловое содержание скота, не известные в то время тувинцам. Тувинцы вели кочевой образ жизни, и многие столетия занимались пастбищным скотоводством. Типичным жилищем у тувинцев были войлочные юрты с небольшим набором бытовой утвари. Н.Ф. Катанов писал, что «сойоты жили в юртах. Юрты маленькие, решетчатые, оканчиваются в верху конусом, одною решеткою без перекрестной. В самом верху отверстие решетчатое, через которое проходит дым....» [9; 24].

Следует отметить, что в сфере материальной культуры есть различия между русскими и тувинцами, а в духовной культуре отличия проявлялись прежде всего в религии: если русские исповедовали христианство в форме православия, то тувинцы « по религиозному признаку тувинцы, как и монголы, были буддистами и шаманистами, но в отличие от них входили в систему «тюркского мира» $[7 ; 3$ ]

Необходимо отметить, что переселение русских в Урянхайский край не было исключительным явлением, а представляло собой геополитику России. Российская империя проводила политику расширения своей территории на юг и восток в поисках земель для хозяйственно-экономического развития. Совершенно естественно, что после падения Китайской империи, в состав которой долгое время входила Тува, Россия начала целенаправленно осваивать Урянхайский край, тем самым решая свои аграрные проблемы.

С 1944 года началась новая страница в истории Тувы, когда ТНР вошла в состав СССР на правах автономной области РСФСР. В советский период с 1944 по 1991 годы численность населения за эти неполные полвека увеличилась в 3 с лишним раза. [13; 77]

В советские годы население Тувы ежегодно увеличивалось, новоселами были не только русские, но и представители различных национальностей. В новых условиях это была уже не колонизация, а перемещение населения на основе рационального развития производительных сил и трудовых ресурсов социалистического государства.

В отличие от первых переселенцев, для которых Тува стала второй родиной, новые поселенцы советского периода приезжали сюда по договорам на определенный срок или на постоянное жительство. Это были квалифицированные рабочие, представители технической интеллигенции, учителя, врачи, агрономы, кадровики. Большая часть из них пополнила городское население Тувинской АССР.

В 50-х годах население Тувы увеличилось. Так, в период с 1945 по 1959 годы численность населения Тувы возросла почти вдвое. Быстрыми темпами росла численность городского населения: к началу 70-х годов по переписи населения русские составили $2 / 3$ (75,4\%), а тувинцы - около $1 / 5$ (17,2\%) от его общего числа. Следует отметить, что тувинское городское население в последнее десятилетие советского периода увеличилось, и это связано с естественным приростом и внутриреспубликанской миграцией «из деревни - в город» собственно тувинского населения. Однако этот процесс осложнялся отсутствием опыта приобщения коренного населения к индустриальному труду, прочными традиционными связями основной массы тувинцев с ведением скотоводческого хозяйства и кочевого образа жизни, неграмотно- 
стью преобладающей части скотоводов.

Постсоветский период - в 90-е годы XX века - общая численность населения Тувы осталась на том же уровне. Однако соотношение этнических групп изменилось в результате существенного оттока в начале 90-х годов XX в. русского населения, а численность тувинского населения возрастала за счет естественного демографического прироста.

Межэтнические взаимосвязи русских и тувинцев в советское время, как показано выше, осуществлялись сначала виде торговых отношений, затем в ходе хозяйственной деятельности, кроме того в трудовом и бытовом общении. В советский период межэтнические контакты в основном были в городе и городской среде - производственно-трудовой деятельности, а так же внепроизводственной (на семейно-бытовом уровне). Эти виды межэтнического взаимодействия осуществлялись как на групповом, так и индивидуально-личностном уровнях.

В советский период межэтническое взаимодействие русских и тувинцев происходило во время индустриализации республики. После вхождения в состав СССР в 50 - 70-х гг. XX в. при помощи Советского Союза Тува превратилась в индустриально-аграрную республику. Ярким показателем индустриального развития за 30 лет (1945 - 1975 годы) является увеличение объема промышленного производства более чем на 50 раз. [14; 29]

За несколько лет были сооружены и введены в строй крупные комбинаты общесоюзного значения - «Тувакобальт», «Туваасбест». Учитывая богатства природных ресурсов республики, стали развивать предприятия лесное деревообрабатывающей, горнодобывающей промышленности. В Туве, как и в других регионах Советского Союза, на базе всех отраслей производства был создан высокоэффективный территориально-производственный комплекс (ТПК).

Наряду с успешным развитием промышленности в Туве началась урбанизация, т.е. увеличение городского тувинского населения, формирование которого происходит в результате сложного естественного движения и миграционных процессов. Одним из источников роста численности городского населения является тувинское село. Основным фактором пополнения городской инфраструктуры и экономики в Туве стала система образования и подготовка кадров, а источником пополнения городского населения была тувинская молодежь - выпускники техникумов и профтехучилищ.

Основными формами этнического взаимодействия русских и тувинцев в производственной и непроизводственной сфере, в быту, культуре, учебе были межличностные общения в трудовых коллективах, на досуге и между семьями. Конкретными формами межэтнических контактов в процессах межэтнического взаимодействия русского и тувинского этносов, как и других народов, являлись ассимиляция и адаптация.

В отношении ассимиляции, суть которого заключается в потере этносом языка, культуры, обычаев и традиции, в истории межэтнических взаимодействий между русскими и тувинцами она имела ограниченный характер. В дореволюционный период были только единичные случаи ассимиляции, поэтому можно сказать, что фактически она не встречалась. Как писал Н.Ф. Катанов, «взаимные мирные отношения урянхайцев и русских установились в последнее время настолько прочно, что девицы урянхайские нашли возможность выходить замуж за русских. Из живущих на Бом-Кемчике русских, женатых на урянхайских (сойотках) - следующие лица:

1. Василий Абрамов Спирин, инородец Абаканской инородной управы (минусинский округ) жена Сат сумына, Бейс-хошуна. Урянхайское имя жены Бидикей, а русское - Евдокия.

2. Василий Андоеевич Бяков, минусинский мещанин. Жену его зовут по-урянхайски Тюкей, а порусски Татьяна Изотиевна.

3. Леонтий Иванов Бяков, минусинский купеческий сын. Жену Л.И. Бякова зовут по-урянхайски Пичикей, сумына Сарыглар, ведомства Бейс-хошун.

4. Филипп Аппосов, инородец Минусинского округа. Жена его, по имени Ильдирга, сумына Тонгак, ведомства Бейс-хошун.

5. Бабьян Топоев, инородец Минусинского округа. Жена его - не крещена, имя ее Азыракай, сумына Кулар, ведомства Бейс-хошун.

6. Прокопий Емелянович Тузмин, инородец Абаканской инородной управы (Минусинский округ). Жену зовут по-урянхайски Торла, по-русски значит «рябчик». Не крещенная. Кроме этих лиц, есть и другие, женатые на сойотах и живущие в других местах. Урянхайские власти претензий о женитьбе русских на их подданных никаких не предъявляли. Русские, если желают взять замуж сойоток, должны сватать их по урянхайским обычаям, т.е. с подношением подарков. Впрочем, некоторые берут жен и по русским обычаям».

В советское время ассимиляция существовала в виде политики русификации. С начала 30-х годов партийно-политическое руководство СССР стало проводить пропаганду в отношении других народов под лозунгом интернационализации с первенством в нем русского народа как «старшего брата» в семье советских народов и национальностей.

Теперь рассмотрим адаптацию как наиболее часто встречающийся тип межэтнических контактов, проявляющийся в приспособлении конкретного этноса к 
природной и социально-культурной среде. В русско-тувинских отношениях она проявлялась по-разному как у тувинцев, так и у русских.

Так, в дореволюционный период процесс адаптации у первых русских переселенцев к совершенно новым природным и социальным условиям протекал благополучно и нормально.

В советский период адаптация к природным условиям Тувы у русских новоселов отличалась мало от прежнего. Условия адаптации были лучше, поскольку новое поколение новоселов прибывало в обжитую среду и имело больше возможностей для освоения природы, например, с помощью машинной техники. К тому же более благоприятными были социальные условия. Так, для приезжих специалистов и квалифицированных рабочих создавались привилегированные условия, их обеспечивали жильем, работой, хорошими окладами, отпусками и курортами. В большинстве русские новоселы оставались в городах, где условия жизни и обеспечение были намного лучше, чем в сельской местности.

Вместе с тем необходимо отметить, что процесс адаптации тувинцев к городу был достаточно сложным. Так, в книге «Городское население Тувинской АССР» (Новосибирск, 1981) есть раздел, в котором проанализированы особенности социальной адаптации тувинцев к новым видам труда и к жизни в городе. Авторы показывают, что «переезд в город коренных жителей республики - тувинцев, представлял собой сложнейший переворот во всем образе жизни и сознании. Такой переход связан с необходимостью адаптации к новым темпам и ритмам жизни, к работе часто в закрытом помещении, строгой регламентации рабочего и нерабочего времени, к другим специфическим особенностям индустриального производства». [13; 125].

Заключение. На конкретном фактическом материале, с использованием многочисленных (в том числе, последних) исследований показано, как исторически происходило межэтническое взаимодействие и формирование русского населения в Туве, как русские пришельцы в титанической борьбе с природой осваивали свободные земли и превращали в пригодные для жизни по существу безлюдные пространства сурового, но прекрасного края. Данное исследование позволило установить следующее. Во-первых русско-тувинские отношения стали осуществляться в виде торгового обмена, кроме этого, желание приобрести земли, богатыми полезными ископаемыми, удобные для занятий землепашеством. Во-вторых русские специалисты в 20-40-х годах XX в. сыграли незаменимую роль в создании экономического и культурного потенциала молодой республики. При их всесторонней помощи также осуществлялось формирование национальных кадров рабочего класса в промышленности, строительстве, возникла национальная интеллигенция, сложились квалифицированные кадры в сфере политического и экономического управления. Интеллигенция и служащие русской национальности до сих пор занимают важное место в различных сферах экономики, культуры, образования. В-третьих, не смотря на происходивший в течение XIX - XX вв. рост населения края, численность русских жителей Тувы продолжает оставаться не значительной.

\section{ЛИТЕРАТУРА}

1. Арутюнян Ю.В., Дробижева Л.М., Сусоколов А.А. Этносоциология: Учебное пособие. - М.: Аспект Пресс, 1999. - 193 с.

2. Африканов А.М. русская торговля в Урянхайской земле // Изв. ВСОИРГО (Иркутск). 1890. Т. XXI. № 5.35 С.

3. Вайнштейн С.И., Москоленко И.П. Тувинцы // Сибирь: этносы и культуры. - Москва-Улан-Удэ, 1997. - С.3-26.

4. Грум - Гржимайло Г.Е. Западная Монголия «Урянхайский край». - Т.ІІІ. - Л., 1930. -587с.

5. Дулов В.И Социально-экономическая история Тувы. XIX - начало XX века.- М., 1956. - 361с.

6. История Тувы: В 2т. - т.1.-2-е изд. Іпод ред. С.И.Вайнштейна, М.Х. Маннай-оола. - Новосибирск: Наука, 2001 - 367с.

7. История Тувинской Народной Республики в архивных документах. 1921 - 1944 гг. - Новосибирск: Сибирское книжное издательство, 2011. - 312 с.

8. Карнышев А.Д. Межэтническое взаимодействие в Бурятии: социальная психология, история, политика. -Улан-Удэ: изд. БГУ, 1997. -187с.

9. Катанов Н.Ф. Очерки Урянхайской земли. Дневник путешествия, исполненного в 1889 году. - Кызыл: изд. 000 «Кооператив «Журналист», $2001 .-383$ с.

10. Кон.Ф. Экспедиция в Сойотию // За пятьдесят лет. - М., 1934. Т.3. - 549с.

11. Москаленко Н.П. Этнополитическая история Тувы в XX веке - М.: Наука, 2004, - 222 .

12. История советско-тувинских отношений (1917-1944 гг.): Монография. - М.: изд. Московского гуманитарного университета, $2005,-326$ с.

13. Городское население Тувинской АССР. - Новосибирск: изд. Наука, 1981 - 222 .

14. Народное хозяйство Тувинской АССР в девятой пятилетке. Стат. Сб. - Кызыл, 1979. - С.213.

15. Тавадов Г.Т. Этнология. Учебник для вузов. М.: Проспект, 2004,с.352

16. Татаринцева М.П. Старообрядцы в Туве: Историко-этнографический очерк - Новосибирск: Наука, 2006 - 216 с. 